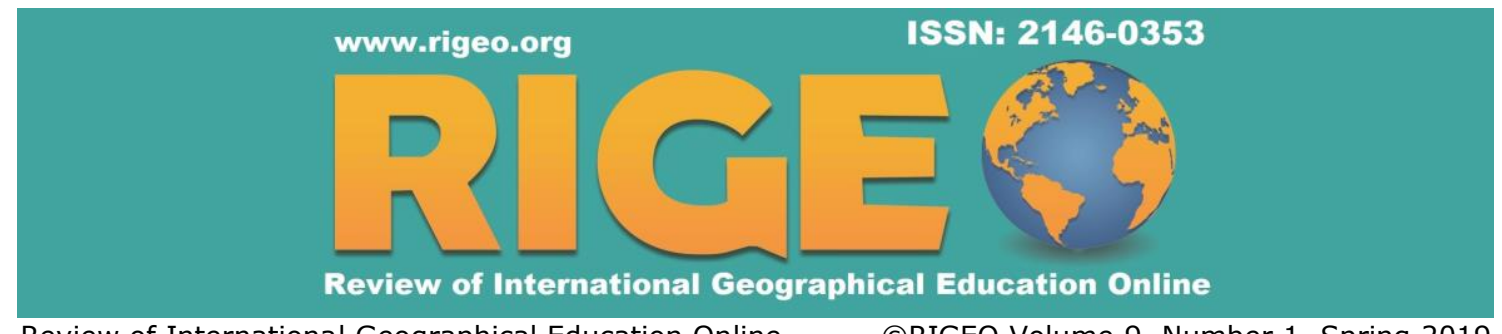

Review of International Geographical Education Online

(C)IGEO Volume 9, Number 1, Spring 2019

Research Article

Copyright $\odot$ RIGEO 2019

To cite this article: Pamuk, I., Öztürk, C., Akengin, H. (2019). Geography Courses in the Identity Construction and Spatial Belonging Development of Turkish-origin Students Living in Germany. Review of International Geographical Education Online (RIGEO), 9(1), 63-81. Retrieved from http://www.rigeo.org/vol9no1/Number1Spring/RIGEO-V9-N1-3.pdf DOI: $10.33403 /$ rigeo. 573472

Submitted: July 6, 2018

Revised: December 21, 2018

Accepted: March 6, 2019

\title{
Geography Courses in the Identity Construction and Spatial Belonging Development of Turkish-origin Students Living in Germany*
}

\author{
İrem PAMUK ${ }^{1}$ \\ University of Health Sciences, Istanbul, TURKEY \\ Cemil ÖZTÜRK ${ }^{2}$ \\ University of Marmara, Istanbul, TURKEY \\ Hamza AKENGİN 3 \\ University of Marmara, Istanbul, TURKEY
}

\begin{abstract}
The aim of this study is to find out the contributions of geography courses to the spatial belonging development and identity construction of Turkish-origin students from different types of schools located in North Rhine-Westphalia (Nordrhein-Westfalen) state in Germany. In this study, one of the qualitative research designs, namely phenomenology, will be employed. Phenomenology is the most suitable methodological tool for this study, as it enables us to focus on experiences, livings, thoughts, sense, and feelings of individuals. The study group was determined in accordance with purposive sampling. The data was collected through semi-structured interviews and analyzed with the "MAXQDA 11" qualitative data analysis software and categories were formed. According to the research results, Turkish-origin students are aware of the important role that geography courses take firstly in familiarizing with Germany, the country they live in. It was revealed that geography courses
\end{abstract}

*This paper is based on $\mathrm{PhD}$ thesis titled "Contributions of German Citizenship Education to the Identity Construction and Belonging Development of Turkish-origin Students" Thesis was supported by Scientific Research Projects Coordination Unit of Marmara University (EGT-C-DRP-100615-0308).

${ }^{1}$ Corresponding Author: Assist. Prof. Dr., University of Health Sciences, Faculty of Health Sciences, Istanbul, Turkey, E-mail: iremkab [at] gmail.com. ORCID: 0000-0002-9214-6044

2 Prof. Dr., University of Marmara, Atatürk Faculty of Education, Istanbul, Turkey, E-mail: cozturk [at] marmara.edu.tr. ORCID: 0000-0002-2433-350

3 Prof. Dr., University of Marmara, Faculty of Science and Letters, Istanbul, Turkey, E- mail: hakengin [at] marmara.edu.tr . ORCID: 0000-0002-0626-3819

(C) Review of International Geographical Education Online

RIGEO 2019

ISSN: 2146-0353

www.rigeo.org 
provide students with the sense of spatial belonging and help them to embrace the place they live in by creating a certain perception of place. In other words, Turkish-origin students feel that they are part of Germany because they feel that they belong to the place. The fact that they see Germany as their home country is one of the indicators of interiorizing the geography. For them, Germany is their home country whereas Turkey is their motherland. As their families' motherland concept is related to Turkey, they transmit the concept of motherland from their families to their social realities.

Keywords

Spatial Belonging; Perception of Place; Geography Course; Germany; Turkish-Origin Students; Phenomenology

"Geography means the explanation of the nature, actually the whole earth.
Geography and history fulfill the whole of our understanding;
geography is for one related to the place and history for one related to the time."

Kant (1839, p. 428)

Education is the principal building block in the process of learning, maturation, developing character and constructing the identity of the individuals (Bla $\beta, 1978$, p. 19; Giroux, 2014, p. 20; Kant, 1964, p. 697; Tanilli, 2007, p. 11-13). At the same time, education has expectations from the individuals; it requires them to be ideal citizens. Citizenship education, in its turn, is based on human's relationship with time, space, society, his/her own self and with other individuals. It also plays a significant role in the formation of ideas, identity construction, development of the sense of belonging and participation of an individual in the society as a citizen (Benjamin, 2001, p. 89; Öztürk \& Dilek, 2003, p. 49; Öztürk, 2007, p. 101, 106).

The essential subject of geography is the interaction between humans and places. Geography is mainly concerned with people's perception of places, their knowledge about the place where they live and daily events and experiences associated with the place. It is directly related to the daily life. It is directly related to our daily life and aimed at developing a sense of belonging to a certain place and providing people with information about their environment, about the ways of behavior depending on the environment (Akengin, 2007, p. 149, 150; Akengin, 2009, p. 203-204; Bahr, 2007; Özey, 2010, p. 1). "Geography contributed to the development of citizenship by helping students understand local, national, and global environmental and civic issues" (Bednarz \& Bednarz, 2015, p. 235). Belonging is an inherently geographical concept. The feeling of spatial belonging is created through spatial relationships and daily routines (Kuusisto-Arponen, 2014, p. 435; Mee \& Wright, 2009, p. 772). The acceptance of a place and attribution of meanings to it develop spatial belonging. Spatial belonging that emerges after a place gains meaning is at the same time one of the important constituents of identity construction. In other words, the place is an important part of identity (Mai, 2005, p. 107, 112).

Geography, especially human geography, is one of the courses that are citizenship education centered. "Citizenship and geography education share a common goal: the preparation of students to be well- informed citizens capable of making informed civic decisions. An informed citizen has the capacity to participate in decision- making processes to address the common good for the community in which they live, for the country to which they belong, and for Earth, which they inhabit." (Stoltman, 2019). 
This type of education facilitates the development of spatial belonging and prepares future citizens for a life in society.

In Germany, citizenship education has gained so much importance following the destruction caused by the Word War II. In order to prevent such thing from happening again, teachings of democracy became really important, and citizenship education in Germany is mainly focused on the acquisition of democracy consciousness from an early age.

Following the destructive war, Germany was divided into two parts as the East and the West, and its economy came to a dead end. There was a huge lack of workers in the West Germany. As a result, it started to accept labor from other countries so the economy could develop and revive. Even though Turkey and Germany are very different in terms of culture, two countries signed the bilateral Agreement on Labor Recruitment (Anwerbeabkommen) in 1961, and Germany started to accept workers from Turkey (Çakır, 2015, p.61-62). At the beginning of labor migration, Turkish workers were supposed to come for a certain period of time and then return to Turkey (Çil, 2011, p.48-49). However, as the time went by, Turkish-origin individuals settled in Germany and formed their own diaspora. Safran (2015, p. 97), who sees diaspora as a special formation of migrants, states as follows: "Because they keep a memory about a general tend related to their homeland with a cultural connection; they have institutions that reflect something about homeland culture and religion; they are keen on symbolic and practical homeland." In this context, Safran (2015, p.100) emphasizes the multidimensional relation between the "two worlds", which is experienced in the diaspora: the country of residence and the motherland.

The role of the geography courses in shaping the spatial belonging development cannot be underestimated. This research is an attempt to identify the contributions of geography courses, which form an essential part of citizenship education at schools in the North Rhine-Westphalia, in the identity construction and the development of spatial belonging of Turkish-origin students. The main research question is "What are the contributions of geography courses in Germany to the identity construction and spatial belonging development of Turkish-origin students?" The sub-questions of the research are:

1. What is geography according to Turkish-origin students?

2. What is the aim of the geography courses according to Turkish-origin students?

3. What are the subjects that Turkish-origin students are taught in geography courses?

4. What are the contributions of geography courses according to Turkish-origin students?

5. How much are Turkish-origin students interested in geography courses?

6. What are the opinions of Turkish-origin students about not having subjects related to the geography of Turkey in geography courses in Germany? 


\section{Methodology}

\section{Research Design}

As underscored in the introduction part, this research focuses on the contributions of geography courses, which are taught as part of citizenship education in German schools, in the identity construction and development of spatial belonging among Turkish-origin students. It was necessary that the students were born in Germany and raised in a diasporic environment. Apart from the contributions, this study sheds light on what geography courses mean to students and how they make sense of the courses through their personal experiences from their own point of view. It is very important to focus on the everyday lived experience of students in educational situations (Van Manen, 1990). The research is carried out through a methodological tool called phenomenology. Phenomenology is one of the qualitative research designs that makes it possible to particularly focus on perceptions, meanings they attribute in relation to places, life as well as learning experiences of Turkish-origin students from their point of view (Neuman, 2014; Yıldırım and Şimşek, 2008, p. 79).

Phenomenological research focuses on an individual's lived experiences, lifeworld, thoughts, perceptions, emotions etc. Phenomenology is concerned, first and foremost, with human experience and focuses on how life is experienced. Phenomenology is the study of the lifeworld and oriented to the practice of living. The source data of the phenomenon are the individuals who experience and live the phenomenon that the research focuses on; the data collecting instrument is the observations and the semistructured interviews to find out the perceiving and experiences related to phenomenon (Baş, Usta \& Uyar, 2008, p. 111-112; Denscombe, 2010, p. 94, 95; van Manen, 1984, p. 37; van Manen, 2007, p. 13; Yıldırım \& Şimşek, 2008, p. 72- 75).

This study is limited to the research problem, its phenomenological design, and the study group. And it is intended to determine the thoughts and perception of 38 Turkishorigin students who live and go to school in Germany. The findings of this study only represent this study group.

\section{Study Group}

The study group of the research was selected by purposeful sampling. The study group of the research consists of 22 girls and 16 boys, 38 Turkish-origin students in total specified via purposeful sampling method who studies at the different types of schools (Hauptschule, Realschule, Gesamtschule, Gymnasium, Berufskolleg, university) in Nord Rhine- Westphalia state in Germany. Demographic information about the Turkish- origin students who participated in the study was given in Table 1. 
Table 1

Information about the Students in the Study Group

\begin{tabular}{|c|c|c|}
\hline & & Frequency \\
\hline \multirow[t]{3}{*}{ Gender } & Total & 38 \\
\hline & Girls & 22 \\
\hline & Boys & 16 \\
\hline \multirow[t]{9}{*}{ Age } & 11 & 6 \\
\hline & 12 & 7 \\
\hline & 13 & 9 \\
\hline & 14 & 6 \\
\hline & 15 & 4 \\
\hline & 16 & 2 \\
\hline & 17 & 2 \\
\hline & 18 & 1 \\
\hline & 19 & 1 \\
\hline \multirow[t]{7}{*}{ Type of schools } & Total & 6 \\
\hline & Hauptschule & 1 \\
\hline & Realschule & 19 \\
\hline & Gesamtschule & 8 \\
\hline & Gymnasium & 6 \\
\hline & Berufskolleg & 3 \\
\hline & University & 1 \\
\hline \multirow[t]{6}{*}{ Class } & 6.class & 6 \\
\hline & 7.class & 9 \\
\hline & 8.class & 9 \\
\hline & 9.class & 7 \\
\hline & 10.class & 2 \\
\hline & 11.class & 1 \\
\hline
\end{tabular}

\section{Data Collecting Instruments and Process}

Phenomenology helps us to understand originary and insights into the phenomenality of human experiences. And focuses on the personal experience and on views of participants to explore the meaning of a certain phenomenon or event (Van Manen, 2017, p. 778- 779). The most efficient method to find out the context of spatial belonging of Turkish-origin students through geography is asking directly to them. To interpret their experiences during identity construction and spatial belonging development processes "Asking others how they constitute the reality...and (rather than stridently and as a priori, emphasizing it by us) it would be better to ask with a style and deepness letting them use their own terms and express the rich context of their own." (Jones, 1985, p. 46 as cited in Punch, 2011, p. 166).

During the research process, data were collected via semi-structured, in-depth interviews and group interviews to have an efficient interaction among students. So, a better understanding of Turkish-origin students' views and behavioral patterns became possible, rich data and holistic view are achieved. 
Pamuk, I.., Öztürk, C., Akengin, H. (2019) / Geography Courses in the Identity Construction and....

\section{Analyze of Data}

In phenomenology researches it is in the foreground to find out the reality of the living in analyzing data and to do so, to regard and to interpret the sense and actions indepth. In analyzing of context, texts that emerge with the transcriptions of recorded conversations which are the results of social interactions and the important expressions obtained signally related to phenomenon are described. Expressions and meanings should contain the essence of phenomenological experience (Berg \& Lune, 2015, p. 381- 385; Christensen, Johnson \& Turner, 2015, p. 409, 410; Öktem, 2005, p. 30).

Interviews, made with 38 Turkish-origin students who form the study group of the research, were recorded by voice recorder getting the permission of their parents and themselves. Recordings were transcribed word by word on the Microsoft Word program and texts are constituted. The expressions of Turkish-origin students were written down exactly without any correction. All the texts were read several times in detail to get a holistic approach about students' experiences related to the phenomenon and then data were started to be analyzed. The collected and recorded data have been analyzed via the techniques of content analysis. Themes are derived from codes. After all interviews were coded, categories were constructed. Content analysis was used to interpret the transcripts of the interviews through "MAXQDA 11" qualitative data analysis software. The data were coded and the codes were grouped similar codes. The themes that represent the pattern of the data were found out to describe the contributions of geography courses that Turkish-origin students living in Germany are taught in Germany to their identity construction and spatial belonging improvement. For the reliability of the study, each of the researchers formed their own analysis categories and compared each other. Findings were given quoting the answers of Turkish-origin students exactly. And findings were interpreted within the scope of themes and patterns found.

\section{Findings}

\section{The Opinions and Experiences of Turkish-Origin Students about Geography Courses}

The place is a platform that those who live on perceive and affect with their actions, are effected and use. There is an interaction between human and the social and physical place he/ she lives in. People and places they are involved influence each other mutually. According to Kant, geography enhanced the sense focused on time and place. Kant explains this factual situation: "Geography means the explanation of nature, actually the whole earth..." (Kant, 1839, p. 427). Geography is about place. Geography as a science that studies the relations of people with the place they live on; studies the interactions among people, places and people with places. With its detailed approach to people and their relation with place, it is defined as a field focused on human (Bell, 2005, p.13 as cited in Kolnik, 2011, p. 17; Foley \& Janikuoun, 1996, p. 1 as cited in Akengin, 2007, p. 143; Özey, 2010, p. 1). Geography has a function to get to know and introduce the place. So, on the one hand, it develops a sense of place by forming the human relation with his environment and living; on the other hand, it provides to get 
onto how people influence their environment, deepens this sense for students to internalize (Akengin, 2007, p. 147- 152).

An individual is born within a natural and social environment. $\mathrm{He} /$ she is influenced by this environment while his personality is being shaped. Geography, with the knowledge it gives about place, provides individuals to have an interaction with the place they live on and so improve their spatial belonging (Akengin, 2007, p. 146- 150; Akengin, 2009, p. 203, 204; Öztürk \& Dilek, 2003, p. 61, 78; Öztürk, 2009, p. 8, 20). To sum up, geography contributes to identity construction, spatial belonging development, and citizenship consciousness by familiarizing the place, giving the knowledge to form the living space and life itself. It is important to know the culture, the society being lived in and the physical and humane reasons for the individual to have a citizenship consciousness and identity construction.

German geography in the context of the relation established by the individual with the place is a part of the social reality of Turkish-origin students. The contributions were found out to the identity construction, spatial belonging of Turkish-origin students who frequently encounter information of a different country's geography in Germany than their own (Turkey). In scope of the interviews, as a group or one by one, done with Turkish-origin students having education in North Rhine-Westphalia state, data obtained as a results of their analysis, researches are formed under the following titles: 1- The meaning of the geography according to Turkish-origin students, 2- The aim of the geography courses according to Turkish-origin students, 3- The subjects that Turkish-origin students taught in geography courses, 4- The contributions of geography courses according to Turkish-origin students, 5- The interests of Turkish-origin students in geography courses and 6- The opinions of Turkish-origin students about not having subjects related to geography of Turkey in geography courses in Germany.

The meaning of the geography according to Turkish-origin students. Everything that experiences in daily life is directly related to the place of living on it. Geography courses at school give the knowledge of the place to students (Akengin, 2009 , p. 203). According to research findings, geography reminds to Turkish- origin Students the world, countries and the map. It is understood that there are essential elements of geography in the associations of students.

Öykü (11) mentions things related to the world come to her mind by saying: "When saying geography, I mean natural things or things related to the world." Likewise, elements related to the world evoke according to Ensar (15) saying: "World.", Enise (14): "World.", Fatma (15) “World." For Melisa (12), geography means: "Things from the whole world." Melik (13) says: "It evokes the worlds. It evokes the world; I mean continents and so on." In Melik's (13) perception of geography, an order from the general to the specific is seen. Rana (12) mentions besides the basic concepts of the universe the other planets in the solar system come to her mind with her expression: "Universum (universe). The whole world such as the planets above." Büssra (14) explains: "World, map, sun, the world, well, the world rotates towards the sun." comes to her mind when geography is said. For Büşra (14) geography evokes the rotation of the earth around sun which lasts a year and means the formation of the seasons. Büşra (14) also emphasizes the map that is the key element of geography. Abdülhamit (15) 
expresses that the world and the people spread on it and their living conditions evoke by saying: "In the world, all around the world, well, how to say, something related to the equator, our teacher told about it. Or, when there is hunger around the world, then people who are hungry are below and people who are weak in terms of financial situation stay below." Abdülhamit (15) perceives geography worldwide with its human dimension that is human geography. According to most of the students, geography gives information about the world and the planet system and in this sense, it contributes them to understand the world.

Among students to whom geography evokes the countries, Samet (17) says: "Countries, the features of countries, what is famous there and such." In the same way Eren (13): "Countries, capital cities or so.", Yasemin (13): "It is related to the country, sea or so.", Ensar (15): "Which country is where. There are such things like that at school due to the economy.", Nesibe (11): "City, the town in the world so and so on." and Hazal (11) said: "Something about countries." Geography thinks of students different countries on the world, the location of the countries and their features peculiar to them and major cities. Students regard geography as part of the countries' geography.

For Sermin (13) geography means: "Map, seas." In a similar way Reyhan (11) says like the world, the map also means geography for her: "World, world map, maps, something related to countries." The remarkable thing in students' answers is it forms a macro sense and evokes the world in general, countries, and map in specific.

The aim of the geography courses according to Turkish-origin students. The development of the sense of place starting with the recognition of the place lived in provides individuals to realize the interaction between physical and human environments on earth and to understand the world. Akengin (2009, p. 204) mentions the importance of the role of geography in the perception of place and he states that geography courses or subjects related to geography provide children to perceive the place and the systematic improvement of the sense of environment. Similarly, according to Turkish-origin students the aim of the geography courses is to get to know the world and places, to understand the economic structures, to acquire a general culture and to provide a sustainable life.

The explanation of Aslinur (12): "It shows the world, how it is, how its shape is...how we live, where we live." follows the explanation of Sinem (12) about the aim of geography courses is to get to know the world and place: "They teach the world and countries, they want to teach us...they want us to know." In the same way, Öykü (11) says: "It means to get to know the world better or its countries, I mean its directions just like that." Enise (14): "Wenn wir mal wegreisen wollen, dass wir wissen, wo was ist (when we travel to know what is where). And, we should know, such thing is so important, where Turkey is, where Germany is, where Russland (Russia) is, where America is. We should learn them." and Ensar (15): “...there are maps, they show what is where in Germany, what is where in America, as such." emphasize that knowing geographical location is aimed. Fatma (15) highlights that the aim of teaching geography course could be to get know the world and to know where we live. Abdülkadir (16) states that geography aims to introduce citizens to their countries. 
Cüneyt (14) approaches the aim of geography in a micro way with his expression saying: "To know where we live, namely our Nordrhein Westfalen (North RhineWestphalia), to learn the place we live in." As part of from near to far principal, he mentions that being introduced of the one that is close, the state they live in. To Ahmed (18), geography is to learn the environment that is to say the country which he is one of the citizens in and Europe. The aim of to be introduced of his own living space is also in Ahmed's (18) explanation. Tuba (17) with her expression saying: "Well you are living here but it is to know other places as well." emphasize both the improvement of the place being lived in and a place consciousness in a more macro sense is aimed. Melik (13): "To know things related to that world.", Mustafa A. (16): "To know the world better." and Abdülhamit (15): "Worldwide, I mean how we see the world, what is being done." says that geography aims to give information about the world with their statements. Hazal (11): "It's to get information about the world. I think it's like what we need to do and what we shouldn't do." and Büşra (14): "To get information for how the earth rotates. Under what circumstances people live." highlight that to show the influences of the features of the world and the place lived in on human behaviors and living are among the aims of geography. So, they emphasize that geography aims to show the relation (Akengin, 2007, p. 149) between the world and people living on it. Aydin (19) states that geography consists of Germany centered subjects and creates a sense of Germany, the place they live in: "For example, how rain falls, they show its examples not on the world but only on Germany...I mean it was telling the whole world a little bit, but it was Germany centered. After all, we are living here and at least we know the places we live in." emphasizes that with geography courses teaching the features of the place being lived into students is aimed. It is understood that students are aware that geography plays a role in recognizing Germany, in which country they live in. Students stated that geography aims to construct and develop a sense of place by introducing the world and place.

About the aim of geography course related to teaching the economic structure, Ümran (12) says: "To learn, for example how miners work, I mean what they are doing." It could be said that Ümran (12) because she lives in North Rhine-Westphalia, one of the states that rich in terms of mine, is effective to give the mine an example. Ensar (15) says: "To see which countries are where, what they are doing." By saying this, he states that it is aimed to teach which economic sectors there are and where worldwide. Abdülkadir (16) with his statement saying: "I mean they are teaching those industries in Germany, how a factory works, what it produces, we were learning them once upon a time... How that of Germany's works, how its economy improves or works, they are teaching like that." within the scope of economic structure of Germany, he states that to introduce the work and production area of industrial districts and industrial activities is aimed. Students emphasized economic geography which studies spatial range of economic activities.

According to some of the students, geography aims to acquire general knowledge. About geography courses' aim to acquire general cultural knowledge Aydin (19) says: "Exactly, it is a little bit like general knowledge." Tuba (17): "Not to be ignorant." and she mentions geography aims to improve general knowledge, to get to know the world, 
to have the knowledge and so to develop oneself. Abdülkadir (16) mentioning geography aims to acquire general knowledge explains his example by saying: "How potato comes to home and so."

Mustafa K. (13) emphasizing geography aims a sustainable life says: "Now our environment is getting dirty. So, as long as the world goes on our environment will get dirty, generations will grow up and know how to live in the future because there will be obstacles it is taught today so that our environment will be clean in the future and to have a world that is able to live in." Students expressed that geography contributes today how to live without harming ecological balance and putting the next generations at risk and to settle this consciousness.

The subjects that Turkish-origin students are taught in geography courses. Turkish-origin students told about subjects that they have been lastly taught or impressed, mostly remembered about which subjects they are taught at geography courses. In this sense, at geography courses, they stated that they are taught subjects about world geography, environment, and ecology, German geography, human geography, climate, subjects focused on Europe.

A large part of the students emphasized that subjects related to world geography and in this sense subjects about different countries are told. Enise (14) stating that they learned world geography and saw the lives of people in different regions around the world and under different circumstances in geography course: "Erste, zweite reiche Welte (the first and second rich world countries) now we are talking about. The first riches are like Germany and the second is like Serbien (Serbia), Greek and so. And the third is like Africa, dritte Welt (the third world). Because why we are talking, our teacher puts images, we have such thing overhead projector, we talk about it, and we see that they have no money, no food, and no clothes. And we think why, what we can do and so on. We are making vergleichen (comparison)." In addition to this, Enise (14) meaning The United States by saying "the first riches" and "like Germany" puts Germany she lives in, in the first class country. This categorization of Enise (14) carries traces of Eurocentric understanding and as a subliminal message it takes a role in the internalization of classification of people like modern (developed), becoming modernized (developing) and primitive (underdeveloped). Also in this sentence of Enise (14) beside world geography, there are points of human geography based on human. Rana (12) stating that they see geographical knowledge related to different countries of the world: "We are now doing, well there are verschiedene (different) countries, as such Deutschland (Germany), Africa, and we are talking about them now. Our recent theme is, well, our teacher assigned us a book as homework and there is, well, Germany." and similarly Büşra (14) "We are now Kontinents (continents) there are, Africa, Asia." said and expressed that geography is not only focused on Germany but also the world: "We are starting from a subject, for example in the beginning, where it was, well, it was Arabia and then we skipped to Africa, then to America, to Europe and such." and exemplified what she was taught in geography course. Ahmet (12) says: "In Erdkunde (geography) we are doing, well. Weltraum (space). I mean, from the earth, there is the planet, one by one. For example, we are on the earth, the other things, sun and so on, or the planets." Abdülhamit (15): “We are talking about approximately the 
whole world." and Sermin (13): "For example Africa, which country is where and so on we are doing such things." state that subjects of world geography are taught. After saying that geography subjects are not only focused on Germany Yasemin (13) added: "We did about, well, the biggest Berge (mountains)...also the world geography." Berkay (14) said it is not only focused on the geography of Germany and they are talking about world geography as well and said: "From the Nord (north) sea sides then we don't underline Germany that much but we skip to America, Africa or Australia and like that." Aslınur (12) completes saying: "So, well, how it happens, how rain falls, the sun rises, where rain comes from and things like that are shown." the explanation of Sinem (12) saying: "For example, we learn the world. How rain comes they show." Sinem says they get information about the location of the continents and demographic structures: "We did something about Africa, lately. There are which countries, how many people live there and so on we were talking about." Eren (13) says: "We are doing in geography, well, River Nile in Africa, yes Fluß (river)."

Fatma (15) states that there is Turkey in the context of world geography by saying: "There was Turkey, in our...that there are too many earthquakes happen in Turkey." She stated about the earthquake that Turkey was mentioned among the countries in the seismic belt. Abdülkadir (16) stated that there is also Turkey in the subjects they are told at the courses by saying: "They were comparing Germany with other countries; we were doing it by drawing a chart, which countries are the most we were seeing and I was first searching for Turkey. Thank God sometimes Turkey was up, quite up, I was feeling satisfied with it but they were quite comparing Germany with others, how it was going on, the economy and so on." In the same way, Sinem (12) stated that within the scope of world geography, there is also Turkey by saying: "We did something about the world and so on, for example about Turkey, İstanbul." Sinem (12) says: "Nice, I think it's very nice because the others as well are learning about our country, they are seeing images and such, how there is, Grand Bazaar and so on." and Aslınur (12) says: "We are not always talking about their country, we are talking about our country as well." about how they feel about it. The emphasis of Aslinur (12) by saying their country and our country is important. What is meant by saying their country is Germany and our country is Turkey.

Students stated that they are told subjects about the environment and ecology. In this context, Nesibe (11): "For example, we should reduce plastics.", Hazal (11): "Not to throw rubbish into the sea and so on." and Melisa (12): "Which litters they left in the sea, and like that." said what they learned. Nesibe (11) says: "Well, they taught us that earth slides two centimeters each year." and completes Reyhan (11) statement saying: "For example, what has changed from past till now." and emphasized the changing in the natural environment. Fatma (15) stated that they are told natural forces occurring in the natural environment and influence ecology by saying: "We have seen earthquakes or what Vulkan (volcano) is, and such or the underwater earthquakes, tsunamis or so on." In the same way, Mustafa K. (13) states they are told subjects about environment and ecology by his explanation, saying: "How the trees grow, how the world develops, how deserts are formed, how plants are grown in deserts and so on, weather I mean 
how the weather conditions are formed or how spring, autumn, summer and winter are formed."

There are students mentioning there are subjects focused on the geography of Germany in geography courses, as well. Yasemin (13): "The neighbors of Germany or only some parts of it or all or Germany's I don't know how to say, Bundesstaat (state)." and Ümran (12) say: "At fifth grade we were told Länder (states), mining and so on." and states mostly Germany is told. Abdülkadir (16) emphasizes that the course is Germany centered by saying: "Yes, how that of Germany's works, how its economy, how it progresses or works, they are telling it." Ahmet (12) stating that they are told the geography of Germany, its economy, political districts, and its states he sees the reason for it by saying: "Because we are living in Germany." In this statement, there is an emphasis on that geography is related to the place lived in.

Berkay (14) stating that geography courses are formed within the scope of human geography and says: "Shows us, how people built houses or how they earn money. Let's say in South America they plant banana and bring it to Germany. They bring it by ship to us, for us to eat. But the salary is too low I think... We read that they earn one euro or so a day." He stated that he learned the influences of place on people's living in the geography courses and he got a sense of place about the world. Rana (12) stating that they are told states of Germany and demographic details about states in the courses on the basis of the map, by saying: "Landkarte (map). There, we wrote all the states in Germany. Also, we wrote the Bundesstadts (federal capital) of those Staats (states), how many people live there." Abdülhamit (15) states that they are told human geography based on the examples they see in the courses, saying: "...in the world, worldwide, well how to say, they told to learn something about the equator. Or, in the world when there is hunger or so, those who are hungry are below and those who are weak in money are below."

Mustafa A. (16) stating that geography courses are told in a Eurocentric way, says: "We are mostly talking about Europe, how it was in the past and so on." In the same way, Süheda (15) and Büşra (14) state that there are subjects mostly focused on Europe in geography courses. Ensar (15) mentioning geography courses rather teach about Germany and it states and says there a geography teaching focused on Europe: "Europe, something like that."

Erva (12) emphasizes that there are subjects of human geography as well as climate and says: "For example, we are being taught about people from other countries, for example how it rained, when it rained, how it is raining, how many millimeters it is raining. We are being taught things like that." Aydin (19) draws attention to climate subjects saying: "Well, how it is called, atmosphere, or for example climates, and such but not too much." It can be said that the subjects that Turkish-origin students are told in geography courses introduce primarily Germany, the country they live in, and the world, deepen their sense of place and thus this helps them to feel belong to the place and contribute to their spatial belonging. 
The contributions of geography courses according to Turkish-origin students. According to Turkish-origin students, geography courses presented them information, introduced the place and formed a sense of place, provide empathy skills and enhanced their general knowledge. Ahmet (12) states that what he was told in geography courses contributed nothing to him.

A large part of the students said they got information in geography course. Tuba (17) says she got information in geography course: "Well, I know how many countries there are." Melik (13): "We are learning things about the world.", Büşra (14) says: "We are learning what is happening in the world or so on." Ahmed (18) states that what he learned from geography courses he uses it in daily life exemplifying it from his own living: "I think it is an important and a nice thing. To know what is where, this something that needs to be known. Now, well, even in Turkey, to know where to go...going without navigation, this year we went like this. Well, it is good I mean, after all, it is important that you know what is where." In the same way, Eren (13) says: "Now we here zum Beispiel (as an example), we always drive the car to Turkey. To know which country to pass, which city to pass." He emphasized that he benefits the information he got in the geography courses while going to Turkey.

There are students mentioning geography courses introduce themselves the place so they construct a sense of place. Beside Aydin (19) who states that geography courses contribute to getting to know Germany and Europe better and to develop a sense of place, Tuba (17) mentioning that family is an important factor in corroborating what students have been taught in the courses, says: "Well, I think it is something about family. I mean, for example, my mother's and father's German is superb, and you know my mother knows more. For example, there are those who rather mostly speak Turkish. There are those who do not know German that much, they cannot teach it to their children, they learn in Erdkunde (geography), but my father makes us travel a lot, he talks about those things a lot, Erdkunde does not make that much sense to me." She states that the points she could not get in geography courses she learned with the help of his family's knowledge, what they told to her and trips they go together and emphasizes the contributions of having a conscious family. Berkay (14) states that geography courses give information about Germany as a place he lives in and with this information, a sense of Germany is shaped with his statement: "In geography, we are learning about here. How to say, how far is Nordsee (North sea) is or how far Hamburg is or how Brandenburger Tor (Brandenburg Gate) is in Berlin."

Enise (14) emphasizing that subjects she is told in geography courses develop her empathy skill, says: "We want to help, of course, when we see something like that, sind wir schon (we feel so sorry). Because how to say, every day how many children are dying there from hunger, there are illnesses. They cannot get help so much, not each of them can go to school, these things are so bad.", and states that she feels so sorry when she sees them. It is understood that geography courses strengthen empathy skills.

Aydin (19) stating that he gets general knowledge in geography courses, says: "Well, to tell the truth, none of the courses contributes but not to be ignorant, not to be unaware. General knowledge, for sure we should have." It is understood that learning 
geography contributes to general knowledge via information introduced about the world.

The interests of Turkish-origin students in geography courses. The subjects of interest in geography courses that Turkish-origin students are taught are how people live in different places, subjects related to Germany and subjects about the environment and living creatures. Ensar (15) and Fatma (15) stated that all of the geography subjects take their interests. Ensar (15) explains it by saying: "Actually, all of them, I mean whatever we learned. I mean, I want to show Interesse (interest), so I want to learn all well." Ensar (15) is interested in all subjects in geography lessons and therefore wants to learn all of them. In the same way Fatma (15) stated that she likes geography courses and all subjects take her interests.

Mustafa A. (16) is among students who state that subjects related to how people live in different places of the world take his interest, explains it with this: "How Europe is, how other countries live and so on. Because they are living in a different way, and such interessant (interesting)." He also explains that he is interested in other people's livings, as well. Erva (12) is interested: "Information about other people, continents" Abdülhamit (15) explains the subject takes his attention: "That's people who are hungry, why they are hungry, what we can do. Our teacher says what we can do; I mean our teacher tells something to solve the problem." In geography courses, about the problems that the other people face with can emerge in their own life as well, Abdülhamit (15) says: "Yes, in case we have such a problem in our lives as well because worldwide, to all of us, ice caps are melting slowly in Antarctica, such problems occur, in case the same happens for us, what we can do in case of such problem they teach us." Also, it can be said that geography courses develop problemsolving skills of those students who are interested in the problems people living in different places of the world face with.

Mustafa K. (13) who states that subjects mostly related to Germany take his attention says: "The states of Germany." Mustafa K. (13) who is also keen on subjects about the environment and living creatures explains it based on an example they are shown in the geography course: "...world development, the benefits of the trees. For example, well, we have newly learned, there is a mushroom that is the biggest thing in the world. I mean; it is bigger than elephant or giraffe, interesting thing." Mustafa K. (13) is interested in the subjects about the interactions between people and natural forces on earth. Geography courses include real-life practices and the interactions of humans and other living beings with the environment. This is the main reason for the students' interest in geography courses.

The opinions of Turkish-origin students about not having subjects related to geography of Turkey in geography courses in Germany. Some of the students stated that they want to learn the geography of Turkey about not having subjects related to geography of Turkey in geography courses they are told in Germany or having it less, and some others stated that it is enough to learn about the geography of Germany because they are living in Germany. 
Enise (14) adds that actually, she wants to learn geographical information about Turkey and says about not having subjects related to geography of Turkey in geography courses: "We talked about it, well, why Turkey became smaller, it was bigger in the past we looked, now it became a little bit small, and nothing more. But we will learn about the geography of Turkey in tenth grade." Erva (12) and Melisa (12) stated that they are willing to learn subjects about the geography of Turkey. Erva (12) explains why she wants it by saying: "Because our mother and father sometimes lived there. That's why we should learn about Turkey. " It is seen that the familial connection with Turkey plays an important role in willing to have subjects related to Turkey.

Abdülkadir (16) saying that sometimes subjects related to Turkey are taught in geography courses, explains his opinion about the matter: "I think, learning is not needed because we are in Germany, we live in Germany and it is enough to give information about Germany." Hamza F. (14) states that subjects related to Turkey are sometimes told and adds that learning about Turkey is not that much necessary, saying: "When comparing it like that in Turkey, this in Germany, or even in France. It happens like that in Germany but they don't do specifically like Turkey or France." It is possible to see Abdülkadir's (16) and Hamza F.'s (14) views within the scope of the reflection of spatial belonging in Germany. Ensar (15) states that there is nothing about the geography of Turkey in geography courses in Germany and this means nothing to him. It is understood that students have the feeling of spatial belonging in Germany that they set a relation and regard as their country.

\section{Conclusion and Discussion}

Turkish-origin students who reside in Germany, live Turkey on the one hand at home and in the diaspora where the Turkish culture and values are dominant, while on the other hand encounter German culture and values at school and in their social lives. It is of great importance to determine the contribution of geography courses in schools in understanding how diasporic identity construction and spatial belonging develop in Germany.

Geography courses play a crucial role in developing student's awareness of relationships between humans and the place. Geography courses contribute to identity construction and spatial belonging development and besides citizenship consciousness by giving knowledge about living place and forming of the living space and by introducing the place that students live in. The information they acquire about the geography of Germany during geography courses helps them to set relation with the place they live in, in learning the details of living space of Turkish-origin students and so it develops their spatial belonging. Similarly, Brillante and Mankiw (2015) have pointed out, human geography plays a significant role to develop the geographic sense of place. So with this sense of place students understand that they belong in the physical world around them and in the social world they share with other people. And a developing sense of place is linked to a sense of belonging. According to the results of the research, Turkish-origin students approach geography as the world, countries and map. In this approach, the basic elements of geography are seen. According to students, geography courses aim to know the world and places, to understand economic 
structures, to have general knowledge and to provide sustainable life. It is understood that students are aware that geography which describes the earth by basing on the interaction between place and human, takes the role in knowing Germany, the country they live in and the world. In accordance with the aims, the contributions of geography courses to Turkish-origin students are: to acquire information, to introduce the place and to form a spatial belonging, empathy skill and to enhance their general knowledge. Geography courses provide Turkish-origin students to internalize the place they live in and so to develop spatial belonging. Geography courses have importance in the identity construction of Turkish-origin students who develop spatial belonging for Germany via spatial practices in Germany. Turkish-origin students become a part of Germany as long as they feel themselves belong to the place, on the other hand, within the human geography, subjects like population, economic activities and general features of the states provide students to internalize the place they lived in by giving the information about it. In this context, students' descriptions of the land they live in, that is to say Germany, as their country is one of the indicators of internalization of place. About not having or having fewer subjects related to the geography of Turkey that they describe as motherland, while some students say they want to learn it, others say it is enough to learn about the geography of Germany because they live in Germany. It is not seen as a great problem not to have information/ subjects about the geography of Turkey in geography courses because it is less value-laden as comparing with history course and contributes practically while not having subjects related to Turkey history in history courses is regarded as a problem by Turkish-origin students and it is tried to be completed via informal sources (Pamuk, 2019). Although recent studies on the relationship between migration and spatial belonging have increased (Aşkın, 2017; Dietz, 2011; Freist, Kyora\& Unseld, 2019; Hanhörster, 2014; Karaman\& Mursül, 2018; Kochan, 2016; Mee\& Wright, 2009; Mirlotfi\& Jahantigh, 2018; Turut\& Özgür, 2018), there is a lack of literature on this topic in relation to geography education.In conclusion, the contributions of geography courses taught within the scope of a learning domain of social studies, the identities of Turkish-origin students and their belonging to German society different facts in different senses emerge. Geography course functions to provide students to regard Germany as their country by making them feel that they are a part of that place, introducing the place lived on, the geography of that place and the place itself. To them, Germany is their country and Turkey is their motherland. On the other hand, it is possible to say that because of their family's notion of motherland belongs to Turkey, they transfer the notion of motherland from their families to their own social realities.

Nowadays, societies continue to be shaped by migration movements. Many societies today have a multicultural, multi-religious, heterogeneous social structure with the increase of cultural diversity after the migration movements. The schools are also a micro example of this social structure. Students are in school and in their classrooms together with students from different cultures and from different countries of origin. There are many students with migration background in schools. And the courses like geography help the students with migration background in shaping the identity, and play 
a major role in the development of spatial belonging. So it is clear that geography courses provide the students with migration background to integrate into society.

\section{References}

Akengin, H. (2007). Eğitim programlarında coğrafyanın yeri nedir? Coğrafya nasıl öğretilmelidir? A. Oktay \& Ö. P. Unutkan (Eds.). İlköğretimde Alan Öğretimi (143157). İstanbul: Morpa.

Akengin, H. (2009). Zaman ve mekâna ilişkin becerilerin öğretimi. Mekânı Algılama. C. Öztürk (Ed.). Sosyal bilgiler öğretimi. Demokratik vatandaşlık eğitimi (1. ed.), (203-220). Ankara: Pegem Akademi.

Aşkın, D. (2017). The children and their parents: Changing spatial belongings among migrants' generations. Global Journal of Psychology Research: New Trends and Issues. 7(2), 90-99.

Bahr, M. (2007). Bildung für nachhaltige Entwicklung- Ein Handlungsfeld (auch) für den Geographieunterricht?!. Praxis Geographie Heft, 9, (10- 12).

Baş, T., Usta, Y. \& Uyar, E. Ö. (2008). Derinlemesine görüşme. T. Baş \& U. Akturan (Eds.). Nitel araştırma yöntemleri. NVivo 7.0 ile nitel veri analizi, (111-117). Ankara: Seçkin Yayıncilik.

Bednarz, S. \& Bednarz, R. (2015). Brave new world: Citizenship in a geospatially enriched environment. GI_Forum, 230- 240.

Benjamin, W. (2001). Çocuklar, gençlik ve eğitim üzerine (M. Tüzel, Trans.). Ankara: Dost Kitabevi.

Berg, B. L. \& Lune, H. (2015). Sosyal bilimlerde nitel araştırma yöntemleri (H. Aydın, Trans. Ed.). Konya: Eğitim Yayınevi.

Blaß, L. J. (1978). Modelle pädagogischer Theoriebildung. Bd.1.von Kant bis Marx. Stuttgart, Berlin, Köln, Mainz: Kohlhammer.

Brillante, P. \& Mankiw, S. (2015). A sense of place: Human geography in the early childhood classroom. Young Children, 70(3), 16-23.

Christensen, L. B., Johnson, R. B. \& Turner, L. A. (2015). Araştırma yöntemleri. Desen ve analiz (A. Aypay, Trans. Ed.). Ankara: An1 Yayıncilık.

Çakır, M. (2015). Türkiye'de Almancı Almanya'da yabancı olan Türkler. Türk Yurdu, 338, 6071.

Çil, H. (2011). Yarım asır önce: 1961 İşgücü alımı anlaşması'na analitik- eleştirel bir bakış. F. Şen (Ed.). 50. yılında göç, (41-51). Ankara: Kültür ve Turizm Bakanlığı Yayınları.

Denscombe, M. (2010). The good research guide. For small- scale social research projects (4th ed.). Maidenhead: Open University Press.

Dietz, A. (2011). Dimensions of belonging and migrants by choice: Contemporary movements between Italy and Northern Ireland. Berlin: Waxmann.

Freist, D., Kyora, S.\& Unseld, M. (Hg.). (2019). Transkulturelle Mehrfachzugehörigkeit als kulturhistorisches Phänomen. Räume - Materialitäten - Erinnerungen. Bielefeld: transcript Verlag. 
Pamuk, I., Öztürk, C., Akengin, H. (2019) / Geography Courses in the Identity Construction and....

Giroux, H. A. (2014). Eğitimde kuram ve direniş: Bir muhalefet pedagojisine doğru (S. Demiralp, Trans.). Ankara: Dost Kitabevi Yayınları.

Hanhörster, H. (2014). Türkeistämmige Eigentümer in Migrantenvierteln. Soziale und räumliche Mobilität der zweiten Generation. Wiesbaden: Springer VS.

Kant, I. (1839). Vorlesungen über physische Geographie. K. Rosenkranz \& F. W. Schubert (Hrsg.). Immanuel Kant's sämmtliche Werke. Leipzig: Leopold Voss.

Kant, I. (1964). Schriften zur Anthropologie, Geschichtsphilosophie, Politik und Pädagogik- 2. (Kant Werke). Frankfurt am Main: Suhrkamp Verlag.

Karaman, Z. \& Mursül, D. (2018) Meskhetian (Ahiska) Turks in Turkey and their perception of spatial belonging. Open Journal of Social Sciences, 6, 88-103.

Kochan, D. (2016). (Re)placing migrants' mobility: A multi-method approach to integrating space and mobility in the study of migration. Migration Studies, 4(2), 215- 237.

Kolnik, K. (2012). Coming together: Geography and citizenship education for sustainable living. Metodički obzori, 7(16), 17-24.

Kuusisto- Arponen, A.-K. (2014). Silence, childhood displacement, and spatial- belonging. An International E-Journal for Critical Geographies, 13(3), 434- 441.

Mai, U. (2005). Doğu Alman kentlerinde kültür şoku ve kimlik bunalımı. A. Öncü \& P. Weyland (Eds.). (L. Şimşek\& N. Uygun, Trans.). Mekân, kültür, iktidar. Küreselleşen kentlerde yeni kimlikler, (107-116). İstanbul: İletişim Yayınları.

Mee, K. \& Wright, S. (2009). Geographies of belonging. Environment and Planning A, 41(4), 772- 779 .

Mirlotfi, M. R.\& Jahantigh, H. (2018). A survey of the sense of spatial belonging to a destination country among Afghan transnational immigrants (Case study: Border villages in Sistan). Journal of Research \& Rural Planning, 7(3), 1-16.

Neuman, W. L. (2014). Social research methods: Qualitative and quantitative approaches (7. Edition). Boston: Pearson.

Öktem, Ü. (2005). Fenomenoloji ve Edmund Husserl'de apaçıklık (Evidenz) problemi. Ankara Üniversitesi Dil ve Tarih-Coğrafya Fakültesi Dergisi, 45(1), 27-55.

Özey, R. (2010). Coğrafya'da yapılandırmacı yaklaşıma göre öğretmen- öğrenci ilişkisi. R. Özey\& S. İncekara (Eds.), Coğrafya ĕgitiminde kavram ve değişimler (1. ed.), (1-8). Ankara: Pegem Akademi.

Öztürk, C. \& Dilek, D. (2003). Hayat bilgisi ve sosyal bilgiler öğretim programları. C. Öztürk\& D. Dilek (Eds.). Hayat bilgisi ve sosyal bilgiler ögrretimi (3. ed.), (47-81). Ankara: Pegem A Yayıncilık.

Öztürk, C. (2007). Küreselleşme ve bilgi çağında sosyal bilgiler öğretimi. A. Oktay\& Ö. P. Unutkan (Eds.). Illköğretimde Alan Ögretimi, (101- 143). İstanbul: Morpa.

Öztürk, C. (2009). Sosyal bilgiler: Toplumsal yaşama disiplinlerarası bir bakış. C. Öztürk (Ed.). Sosyal bilgiler ögretimi. Demokratik vatandaşlık ĕgitimi (1. ed.), (1-31). Ankara: Pegem Akademi.

Pamuk, İ. (2019). Almanya'da kimlik, aidiyet ve Türkiye kökenli ögrenciler. İstanbul: Yeni İnsan Yayınevi. 
Punch, K. F. (2011). Sosyal araştırmalara giriş: Nicel ve nitel yaklaşımlar (D. Bayrak, H. B. Arslan \& Z. Akyüz, Trans.). Ankara: Siyasal Kitabevi.

Safran, W. (2015). Diasporaların karşılaştırılması ve yapısal çözümlemesi (M. E. Dede, Trans.). M. A. Yolcu (Ed.). Diaspora ve kimlik, (95- 133). Konya: Kömen Yayınları.

Stoltman, J. P. (2019). Preface. Spatial citizenship education. In E. E. Shin\& S. W. Bednarz (Eds.), Citizenship through geography. New York: Routhledge.

Tanilli, S. (2007). Nasll bir eğitim istiyoruz? (3. ed.). İstanbul: Alkım Yayınevi.

Turut, H.\& Özgür, M., E. (2018). Bir kente göçün hikâyesi: Süreçler, bütünleşme ve aidiyet. Coğrafi Bilimler Dergisi, 16(1), 153-180.

Van Manen, M. (1984). Practicing phenomenological writing. Phenomenologv and Pedagogy, 2 (1), p. 36-69.

Van Manen, M. (1990). Researching lived experience. Human science for an action sensitive pedagogy. New York: State University of New York Press.

Van Manen, M. (2007). Phenomenology of practice. Phenomenology\& Practice, 1, 11-30.

Van Manen, M. (2017). But is it phenomenology? Qualitative Health Research, 27(6), 775-779.

Yıldırım, A. \& Şimşek, H. (2008). Sosyal bilimlerde nitel araştırma yöntemleri (7. ed.). Ankara: Seçkin Yayıncılık.

\section{Biographical statements}

Irem PAMUK is assistant professor doctor in the department of Child Development at the University of Health Sciences. Her research interests include social studies education, citizenship education, teaching programs, textbooks and diasporic identitybelonging.

Cemil ÖZTÜRK is professor in the department of Social Studies Education at the Marmara University. His research interests include social studies education, history education, teacher training, the history of Turkish education, and the history of the Republic.

Hamza AKENGÍN is professor in the department of Geography at the Marmara University. His research interests include human geography, political geography, geography education, social studies education. 